\title{
Role of Nano-Silica in Amelioration Salt Stress Effect on some Soil Properties, Anatomical Structure and Productivity of Faba Bean (Vicia faba L.) and Maize (Zea mays L.) Plants \\ El- Emary F. A. A. ${ }^{1}$ and M. M. Amer ${ }^{2}$ \\ ${ }^{1}$ Dept. of Agric Botany, Fac.of Agric., AL- Azhar Univ; (Assiut Branch), 71524 Assiut, Egypt. \\ ${ }^{2}$ Soil, Water and Environment Research Institute, Agriculture Research Center, Giza, Egypt
}

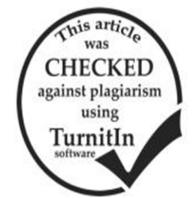

\section{ABSTRACT}

Different levels of foliar applications from nano-silica (i.e., 0, 100, 200, and $300 \mathrm{mg} \mathrm{L}^{-1}$ ), and different salinity combination of irrigation water $\left(0.51,2.45,1.85\right.$ and $\left.1.36 \mathrm{dS} \mathrm{m}^{-1}\right)$ on some soil properties and anatomical structure and productivity of Faba vulgaris $\mathrm{L}$. (Vicia faba L.) cv. Sakha 3 and Maize (Zea mays single hybrid crops cv. Giza 10) plants were investigated in lysimeter experiments at Sakha Agricultural Research Station Farm during summer 2017 and winter 2017/2018 seasons, respectively. Results of soil properties indicated that there are no variations among soil salinity and different foliar application treatments with nano-silica. While, there is a remarkable variation in mean of soil salinity among irrigation with fresh water and blended with well water treatments, which arranged $\mathrm{T}_{4}\left(1.36 \mathrm{dS} \mathrm{m}^{-1}\right)$, followed by $\mathrm{T}_{3}\left(1.85 \mathrm{dS} \mathrm{m}^{-1}\right)$, compared with $\mathrm{T}_{2}\left(2.45 \mathrm{dS} \mathrm{m}^{-1}\right)$, at $0-20 \mathrm{~cm}$ depth for studied plants. A similar trend was also exhibited in the other soil depths. But, exchangeable sodium percentage of the different soil depth unaffected under the same plant. Maize and Faba bean roots and leaves anatomical structure were cleared that at $300 \mathrm{mg} \mathrm{L}^{-1} \mathrm{~N}-\mathrm{Si}$, roots diameter changed up to (22.75, 15.54 and 3.93, $5.97 \%$ ) of Maize and Faba bean respectively, diameter of vascular cylinder (7.95, 6.33 and 1.84, $2.96 \%$ ), and thickness of cortex $(22.77,6.02$ and $2.90,1.69 \%)$ with $\mathrm{T}_{1}$ and $\mathrm{T}_{4}$ treatments compared to the control, respectively. The highest values of big vessel diameter $\operatorname{arch}^{-1}$ were recorded for roots of Faba bean (95.14 and $55.50 \%$ ), with $\mathrm{T}_{1}$ and $\mathrm{T}_{4}$ treatments compared to control. Also, anatomical structure of maize leaves attained 13.80 and $10.43 \%$ for lamina thickness, 16.52 and $4.65 \%$ for midrib length and 7.82 and $31.92 \%$, for number of vesicular bundle midrib ${ }^{-1}$ at $300 \mathrm{mg} \mathrm{L}^{-1} \mathrm{~N}-\mathrm{Si}$ with $\mathrm{T}_{1}$ and $\mathrm{T}_{4}$ treatments more than the control. Also, under the same conditions, mesophyll thickness and midrib length of faba bean leaves recorded $20.07,51.41 \%$, and 35.65, $103.89 \%$, respectively moreover these results will be positively reflected upon chlorophyll content.For productivity, results showed that $\mathrm{T}_{4}$ treatment attained the highest values 4.22, $5.32 \mathrm{t} /$ fed. and 1.74, $1.84 \mathrm{t} /$ fed. in grain and straw yield of Maize and Faba bean plants, under foliar application with $300 \mathrm{mg} \mathrm{L}^{-1}$ of nano-silica compared with other concentrations, respectively. From these results, recommended that foliar application with $300 \mathrm{mg} \mathrm{L}^{-1}$ of nano-silica is the better concentration to mitigation of salt stress effect as well as improvement soil properties, anatomical structure and productivity of Maize and Faba bean plants.

Keywords: Nano-silica, Salinity, Maize, Faba bean,Anatomical structure,soil propertis, Productivity

\section{INTRODUCTION}

The problem of insufficient water resources, that of desertification is looming, certainly dependent on irrational anthropic activities and climatic variations but also linked to the uncontrolled use of poor quality waters and as a consequence agriculture is facing the difficult problem of producing more with ever more limited and worse water resources (El-Shahawy and Ragab, 2005). Direct use of saline irrigation water varying from 0.50 to $3 \mathrm{dS} \mathrm{m}^{-1}$ is common in the districts of Northern Delta where there are no other alternatives or in areas of limited better water quality supply with traditional farming practices. Yield reductions of 25 to $30 \%$ are attributed to water logging and salinization results from poor agricultural, soil and water management, (FAO, 1992).

Maize (Zea mays L.) ranks third in global cereal production and used as food, feed, and fodder. The percent reduction of grain yield was $0,10,25$, and $50 \%$ due to EC of irrigation water of $1.1,1.7,2.5$, and $3.9 \mathrm{dS} \mathrm{m}^{-1}$, respectively (Ayers 1977). Also, grain yield was reduced by $20 \%$ for each unit increase in electrical conductivity of the irrigation water and the soil solution above 1.7 and 4.6 $\mathrm{dS} \mathrm{\textrm {m } ^ { - 1 }}$, respectively (Flávio et al 2008). Also, Faba vulgaris L. (Vicia faba L.) is an important legume crop in Egypt and many parts of the world concluded that grain yield reduction of faba bean (\%) was $0,10,25$, and $50 \%$ due to EC of irrigation water and were $0.7,1.0,1.5$, and $2.4 \mathrm{dsm}^{-1}$, respectively for faba bean, (Ayers 1977).

Silicon ( $\mathrm{Si}$ ) is the second most abundant element in the soil, and considered beneficial to plant growth and production. Recently, several studies have shown that treatment with silicon significantly alleviated environment stresses such as salt, drought, chilling and freezing stress in plants (Liang et al. 2007; Ma and Yamaji 2008), and plays a vital role in a many of metabolic and physiological activities in plants (Bao et al. 2004). Also, Hashemi et al. (2010) observed that silicon nutrition reduced the inhibitory effect of salinity on plant growth by decreasing the $\mathrm{Na}^{+}$content, increasing CAT and cell wall peroxidase activities, and maintaining the membrane integrity of root cells, as demonstrated by reduced lipid peroxidation. According to Epstein (2009) silicon plays an astonishingly large number of diverse roles in plants and does so primarily when the plants are under stressful conditions. Thus, we postulate that the application of nano$\mathrm{SiO}_{2}$ improves plant tolerance to salt stress.

For the interaction between plants and salinity stress, there are several mechanisms: (1) selective ions accumulation/exclusion; (2) control of ion uptake by roots and their transport into leaves; (3) prevention of $\mathrm{Na}+$ and $\mathrm{Cl}-$ accumulation in the cytoplasm; (4) synthesis and accumulation of nontoxic (compatible) osmolytes in the cytosol; (5) change in photosynthetic pathway; (6) induction of antioxidative system; (7) stimulation of phytohormone production, such as abscisic and jasmonic acids. All these mechanisms are realized at the levels of whole plant and plant tissue as well as at the cellularmolecular level (Dajic, 2006).

The effect of salinity on root (An et al., 2003) and leaf anatomy (Hu and Schmidhalter, 2001and Kiliç et al., 2007) of plants had already been reported in previous works. Many researchers reported that with an increase salinity there was a decrease in the development of the xylem. Pimmongkol et al. (2002) stated that the width of vascular bundles and diameters of rice stems decreased in $\mathrm{NaCl}$ medium. Junghans et al. (2006) showed that high salt concentrations reduced the cambial activity in Populus 
euphratica. Salinity causes reduced total leaf area (Awang et al., 1993), and increased leaf thickness (Raafat et al., 1991). Salinity also reduces development of vascular tissue (Belda and Ho, 1993), increases trichome density and decreases or has no effect on stomatal density (Ludders and Kaminski, 1991).

Salinity affects ion accumulation in leaves, thereby membrane permeability and chlorophyll synthesis. Cram et al. (2002) reported two subsequent phases of salt accumulation in leaves of Bruguiera cylindrica, Avicennia rumphiana and A. marina. The first phase is the rapid increase in leaf salt concentration, as it grows from bud to maturity followed by a slower but continuous change in salt content via changes in ion concentration and/or in increased leaf thickness. Increased accumulation of $\mathrm{Na}+$ is generally coupled with reduced $\mathrm{Ca}++$ and $\mathrm{Mg}++$ uptake (Greenway and Munns 1980; Delphine et al. 1998) and sometimes with decline in carbon assimilation (Parida et al. 2004).

Abdul Qados (2015) concluded that nano-silicon treatments can reduce the adverse effects of salinity on $V$. faba plants by enhancing the activity of antioxidant enzymes. Under salinity stress, nano- $\mathrm{SiO}_{2}$ improves leaf fresh and dry weight, chlorophyll content and proline accumulation. An increase in the accumulation of proline, free amino acids, content of nutrients, antioxidant enzymes activity due to the nano- $\mathrm{SiO}_{2}$, thereby improving the tolerance of plants to abiotic stress (Kalteh et al. 2014 and Siddiqui et al. 2014). Silicon nanoparticles (N-Si) have been implicated in crop improvements. Many reports indicate that appropriate concentrations of $\mathrm{N}-\mathrm{Si}$ increase plant growth (Yuvakkumar et al. 2011), plant resistance to hydroponic conditions (Suriyaprabha et al. 2012), and alleviation of the adverse effects of salt stress, increased root length and dry weight of tomato plants, (Haghighi et al. 2012), length roots of the lentil and shoots (Sabaghnia and Janmohammadi 2014). The importance of $\mathrm{Si}$ for improving plant growth was also reported by Roohizadeh et al. (2015) for $V$. faba, and improves the competence of photosynthesis (Liang et al. 2003). Parveen and Ashraf (2010), who found that exogenously applied Si significantly enhanced growth plant and slightly increased photosynthetic rate under saline stress condition in maize

May be yet, no studies were found on the effect of nano silica application under different levels of salinity irrigation water on growth, anatomical structure and yield of maize and faba bean plants. So, this study was conducted to compare the effectiveness of applying nanosilica to mitigate effect of salinity irrigation water on soil properties, anatomical structure and productivity of maize and faba bean plants.

\section{MATERIALS AND METHODS}

\section{Experimental site and treatments}

Two lyzemeter experiments were conducted at Sakha Agric. Res. Station Farm, Kafr El-Sheikh Governorate, Egypt during two seasons (summer of 2017 and winter of 2017/2018) to study the effect of foliar application with different concentrations of nano-silica $(\mathrm{N}$ $\mathrm{Si}$ ) and different salinity levels of irrigation water as well as their interactions on some soil proprieties, anatomical structure and productivity single hybrid of maize (Zea mays cv. 10) and Faba vulgaris L. (Vicia faba L.) cv. Sakha 3 roots and leaves as well as their productivity.

The lyzemeter plot size experiment $(100 \mathrm{~cm}$ x 500 $\mathrm{cm} \times 110 \mathrm{~cm}$ depth), was designed as split- plot with three replicates. The main plots were occupied by water irrigation as: $\mathrm{T}_{1}$ : fresh water $\left(0.51 \mathrm{dS} \mathrm{m}^{-1}\right), \mathrm{T}_{2}$ : well water $\left(2.45 \mathrm{dS} \mathrm{m}^{-1}\right), \mathrm{T}_{3}$ : blended fresh water with well water $\left(1.85 \mathrm{dS} \mathrm{m}^{-1}\right.$ at ratio of $\left.1: 1\right)$, and $\mathrm{T}_{4}$ : blended fresh water with well water $\left(1.36 \mathrm{dS} \mathrm{m}^{-1}\right.$ at ratio of $\left.2: 1\right)$. The subplot,were difoted with different concentrations of nanosilica( 0,100, 200 and $\left.300 \mathrm{mg} \mathrm{L}^{-1}\right)$ as foliar application at 25 and 50 days from sowing. Used nano-silica was provided by National Research Center (NRC), and have characterized by specific surface area $\left(300-330 \mathrm{~m}^{2} \mathrm{~g}^{-1}\right), \mathrm{pH}$ (4.0-4.5), and mean diameter (10 nm).

Maize seeds was sown on May $20^{\text {th }} 2017$ and harvested on September $10^{\text {th }}, 2017$, while faba bean seeds was sown October $20^{\text {th }}, 2017$ and harvested on April $6^{\text {th }}$, 2018. All lyzemeter units received $100 \mathrm{~kg} \mathrm{Fed}^{-1}$ of monosuper phosphate $\left(15.5 \% \mathrm{P}_{2} \mathrm{O}_{5}\right), 50 \mathrm{~kg} \mathrm{Fed} .^{-1}$ of potassium sulphate, $\left(48 \% \quad \mathrm{~K}_{2} \mathrm{O}\right)$. For nitrogen fertilizer, the recommended $\mathrm{N}$ for maize $\left(120 \mathrm{~kg} \mathrm{~N} \mathrm{Fed}^{-1}\right)$ and faba bean (40 kg N Fed. ${ }^{-1}$ ) were added. Other agricultural practices were carried out as recommended by the Ministry of Agriculture and land reclamation.

\section{Soil samples and analysis}

Soil samples were taken at different depths (0-20, $20-40$ and $40-60 \mathrm{~cm}$ ) in the initial and after harvesting of maize and faba bean plants. Exchangeable cations $\mathrm{Ca}^{++}$, $\mathrm{Mg}^{++}, \mathrm{K}^{+}$and $\mathrm{Na}^{+}$, soluble cations and anions as well as soil $\mathrm{pH}, \mathrm{EC}$, exchangeable sodium, organic matter and total calcium carbonate were determined according to Page et al. (1982). Also, $\mathrm{SO}_{4}{ }^{=}$was calculated from the difference between sum of the cations and the anions according to Jackson (1958). Soil bulk density was determined according to Campbell (1994). Field capacity and wilting point were determined by using the pressure plate extractor with regulated air pressure (Garcia 1978) as shown in Table 1. Also, chemical analysis of fresh water, well water and blended irrigation was shown in salinity Table 2 .

Table 1. Some physical and chemical characterizations of the experimental soil.

\begin{tabular}{|c|c|c|c|c|c|c|c|c|}
\hline \multirow{3}{*}{$\begin{array}{l}\text { Soil } \\
\text { depth(cm) }\end{array}$} & \multicolumn{8}{|c|}{ Physical characterizations } \\
\hline & \multicolumn{4}{|c|}{$\begin{array}{l}\text { Soil moisture } \\
\text { characteristics }\end{array}$} & \multicolumn{4}{|c|}{$\begin{array}{c}\text { Particle size distribution } \\
(\%)\end{array}$} \\
\hline & $\begin{array}{l}\text { F.C } \\
(\%)\end{array}$ & $\begin{array}{l}\text { W.P. } \\
(\%)\end{array}$ & $\begin{array}{l}\text { A.W. } \\
(\%)\end{array}$ & $\begin{array}{c}\text { B.D. } \\
\left(\mathrm{kg} \mathrm{m}^{-3}\right)\end{array}$ & $\mathbf{S}$ & Salt & Clay & $\begin{array}{c}\text { Soil } \\
\text { texture }\end{array}$ \\
\hline-20 & 43.5 & 21.2 & 22.3 & 1.28 & & 5 & 50 & clay \\
\hline $0-40$ & 44.2 & 21.9 & 22.3 & 1.29 & 16.7 & 31.9 & 51.4 & lay \\
\hline $40-60$ & 42.5 & 21.3 & 21.2 & 1.31 & 17 & 32.8 & 51.3 & lay \\
\hline \multicolumn{9}{|c|}{ Chemical characterizations } \\
\hline $\begin{array}{l}\text { Soil } \\
\text { depth(cn }\end{array}$ & $\mathrm{pH}$ & $\begin{array}{c}\mathrm{EC} \\
\left(\mathrm{dS} \mathrm{m}^{-1}\right)\end{array}$ & $\begin{array}{l}\text { ESP } \\
(\%)\end{array}$ & $\begin{array}{r}\text { CEC } \\
\text { (cmole }\end{array}$ & -1 & $\mathrm{O}$ & $\begin{array}{l}\mathrm{M} \\
\left.\mathrm{kg}^{-1}\right)\end{array}$ & $\begin{array}{c}\mathrm{CaCO}_{3} \\
(\%)\end{array}$ \\
\hline-20 & 7.95 & 3.10 & 11.70 & 41.2 & & & .54 & 1.91 \\
\hline $0-40$ & 7.98 & 3.45 & 12.47 & 40. & & & & 1.88 \\
\hline $40-60$ & 8.01 & 3.81 & 13.00 & 40. & & & .59 & 1.81 \\
\hline nean & - & 3.45 & 12.39 & 40.6 & & & .97 & 1.86 \\
\hline
\end{tabular}

F.C.: Field Capacity; W.P.: Welting Point; A.W.: Available Water; B.D.: Bulk Density; pH: was determined in soil water suspension (1:2.5); EC: was determined in saturated soil paste extract; ESP: Exchangeable Sodium Percent; CEC: Cation Exchange Capacity; OM: Organic Matter. 
Table 2: Chemical analysis of different irrigation water treatments.

\begin{tabular}{|c|c|c|c|c|c|c|c|c|c|c|c|}
\hline \multirow[b]{2}{*}{ Treatment } & \multirow[b]{2}{*}{ pH } & \multirow{2}{*}{$E C\left(d S m^{-1}\right)$} & \multirow[b]{2}{*}{ SAR } & \multicolumn{4}{|c|}{ Cations (meq $\mathbf{L}^{-1}$ ) } & \multicolumn{4}{|c|}{ Anions (meq $\mathrm{L}^{-1}$ ) } \\
\hline & & & & $\mathrm{Na}^{+}$ & $\mathbf{K}^{+}$ & $\mathrm{Ca}^{++}$ & $\mathbf{M g}^{++}$ & $\mathrm{CO}_{3}{ }^{=}$ & $\mathrm{HCO}_{3}^{-}$ & $\mathrm{Cl}^{-}$ & $\mathrm{SO}_{4}=$ \\
\hline F.W & 7.35 & 0.51 & 3.50 & 3.50 & 0.6 & 1.1 & 0.8 & - & 1.5 & 2.4 & 2.5 \\
\hline W.W & 7.91 & 2.45 & 7.70 & 16.70 & 0.8 & 5.4 & 3.9 & - & 3.5 & 11.7 & 14.0 \\
\hline F.W+W.W (1:1) & 7.81 & 1.85 & 6.70 & 12.60 & 0.8 & 4.1 & 3.0 & - & 3.1 & 8.8 & 10.3 \\
\hline F.W $+W . W(2: 1)$ & 7.46 & 1.36 & 5.80 & 9.20 & 0.6 & 3.0 & 2.2 & - & 2.5 & 6.5 & 7.1 \\
\hline
\end{tabular}

F.W: Fresh Water (T1); W.W: Well Water (T2)

\section{Plant sampling and analysis}

\section{Anatomical structure}

All samples of maize and faba bean were taken after 30 and 35 DAS, respectively to study the anatomical structure i.e., the root diameter (Ø), vascular cylinder diameter (Ø V.C), cortex thickness (mm), big xylem vessel diameter (Ø X.V, mm), vascular bundles number vascular cylinder ${ }^{-1}$ (V.B V.C ${ }^{-1}$ ) and diameter of big vessel $\operatorname{arch}^{-1}(\varnothing$ vessl $\left.\operatorname{arch}^{-1}, \mathrm{~mm}\right)$ for root samples. While, leaves anatomical features were i.e., lamina thickness $(\mathrm{mm})$, thickness of midrib length (mm), thickness of midrib width $(\mathrm{mm})$, thickness of big midrib V.B (mm), diameter of big X.V V.B ${ }^{-1}$ (Ø $\left.\mathrm{mm}\right)$, No. of V.B midrib ${ }^{-1}$, No. of arches, No. of vessels $\operatorname{arch}^{-1}$ and vessel diameter $(\varnothing, \mathrm{mm})$. The sections were computerized morphometrical analysis, the morphmetrical analysis was done by Research Microscope type Axiostar plus made by Zeiss transmitted light bright field examinations apgrad able to professional digital image analysis system (Carl Zeiss Axiovision Product Suite DVD 30). Two samples of root and leaf per plot were collected. Each sample measured $0.5 \mathrm{~cm}$ of the tip portion of the primary root but terminal leaf (maize) and leaflets (faba bean) were taken from the $3^{\text {th }}$ apical internode of the main stem. All samples were killed and fixed for $48 \mathrm{~h}$ in FAA (10 ml formalin; $5 \mathrm{ml}$ glacial acetic acid; $50 \mathrm{ml}$ ethyl alcohol and $35 \mathrm{ml}$ water). The dehydrated samples were infiltrated and embedded in paraffin $\left(52-54^{\circ} \mathrm{C}\right.$ m.p.). The embedded samples were sectioned on a rotary microtome at a thickness of 5-7 $\mu \mathrm{m}$. Sections were mounted on slides and deparaffinized. Staining was accomplished with safranine and light green, cleared in xylene and mounted in Canada balsam (Geriach, 1977). Slides were microscopically examined, measurements and counts were taken and averages of 9 readings of 3 slides were calculated.

\section{Total Chlorophyll content}

Total chlorophyll was determined by Minolta chlorophyll metter SPAD- 502.

\section{Productivity}

At physiological maturity stage, one $\mathrm{m}^{2}$ of three replications were taken to determine grain yield ( $t /$ fed) and strow yield ( $t /$ fed) for both maize and faba bean, the transplanted to ( $\mathrm{t} / \mathrm{fed}$.)

\section{Statistical analysis}

The data were analyzed statistically by analysis of variance (ANOVA) using Cohort Computer Program according to Gomez and Gomez (1984). Differences among means within Treatments were tested using Duncan's - test at the 5\% probability level.

\section{RESULTS AND DISCUSSION}

\section{Soil properties \\ 1. Soil salinity}

Electrical conductivity of different soil depth (0-20, 20-40 and 40-60 cm) for the experimental soil as influenced by different salinity of irrigation water and foliar application with different concentrations of nanosilica after harvesting of maize and faba bean plants are illustrated in Tables 3.

Generally, salinity of soil was increased with increasing of different soil depth. Also, there are no variations between soil salinity and foliar application with different concentrations with nano-silica during the two growing seasons. On contrast, there is a remarkable variation in mean of soil salinity between irrigation with fresh water and blended with well water treatments, which $\mathrm{T}_{3}$ (blended fresh water with well water $1.85 \mathrm{dS} \mathrm{m}^{-1}$ at ratio of $1: 1$ ), recorded 4.32 and $4.47 \mathrm{dS} \mathrm{m}^{-1}$, followed by $\mathrm{T}_{4}$ (blended fresh water with well water $1.36 \mathrm{dS} \mathrm{m}^{-1}$ at ratio of $2: 1$ ), recorded 3.74 and $3.89 \mathrm{dS} \mathrm{m}^{-1}$, compared with $\mathrm{T}_{2}$ (well water $2.45 \mathrm{dS} \mathrm{m}^{-1}$ ), recorded 5.07 and $5.28 \mathrm{dS} \mathrm{m}^{-1}$, at 0-20 cm depth for maize and faba bean plants, respectively. A similar trend was also exhibited in the other soil depth.

From our results, it can be noticed that increasing of values of soil salinity may be due to soluble cations and anions in well water and upon reuse of saline water in irrigating of soils in the terminal end resulted in a remarkable increasing in soil salinity and sodicity as compared to soil irrigated with fresh water. These results are supported by (Amer et al., 2015)

\section{Exchangeable sodium percentage (ESP)}

In lyzemeter experiment, a noteworthy increasing in exchangeable sodium percentage (ESP) was observed in irrigation with fresh water and blended with well water treatments with their corresponding control (fresh water only), after harvesting of maize and faba bean plants (Fig. 1).

Data showed that the mean values of ESP after harvesting of maize was $12.55,14.97,14.72$ and $13.85 \%$ with different irrigation water treatments $\mathrm{T}_{1}\left(0.51 \mathrm{dS} \mathrm{m}^{-1}\right)$, $\mathrm{T}_{2}\left(2.45 \mathrm{dS} \mathrm{m}^{-1}\right), \mathrm{T}_{3}\left(1.85 \mathrm{dS} \mathrm{m}^{-1}\right)$, and $\mathrm{T}_{4}\left(1.36 \mathrm{dS} \mathrm{m}^{-1}\right)$, respectively, at $0-20 \mathrm{~cm}$ depth. Also, for foliar application with different concentrations of nano-silica, ESP of the different soil depth unaffected under the same plant. However, under faba bean plants, soil samples were recorded the highest values of ESP for different soil depth $(0-20,20-40$ and $40-60 \mathrm{~cm})$ as compared to maize plants. 
Table 3. Impact of foliar application with different concentrations with nano-silica and different salinity of irrigation water on soil salinity (dS $\mathrm{m}^{-1}$ ) after harvesting of maize and faba bean during growing seasons 2017 and 2017/2018.

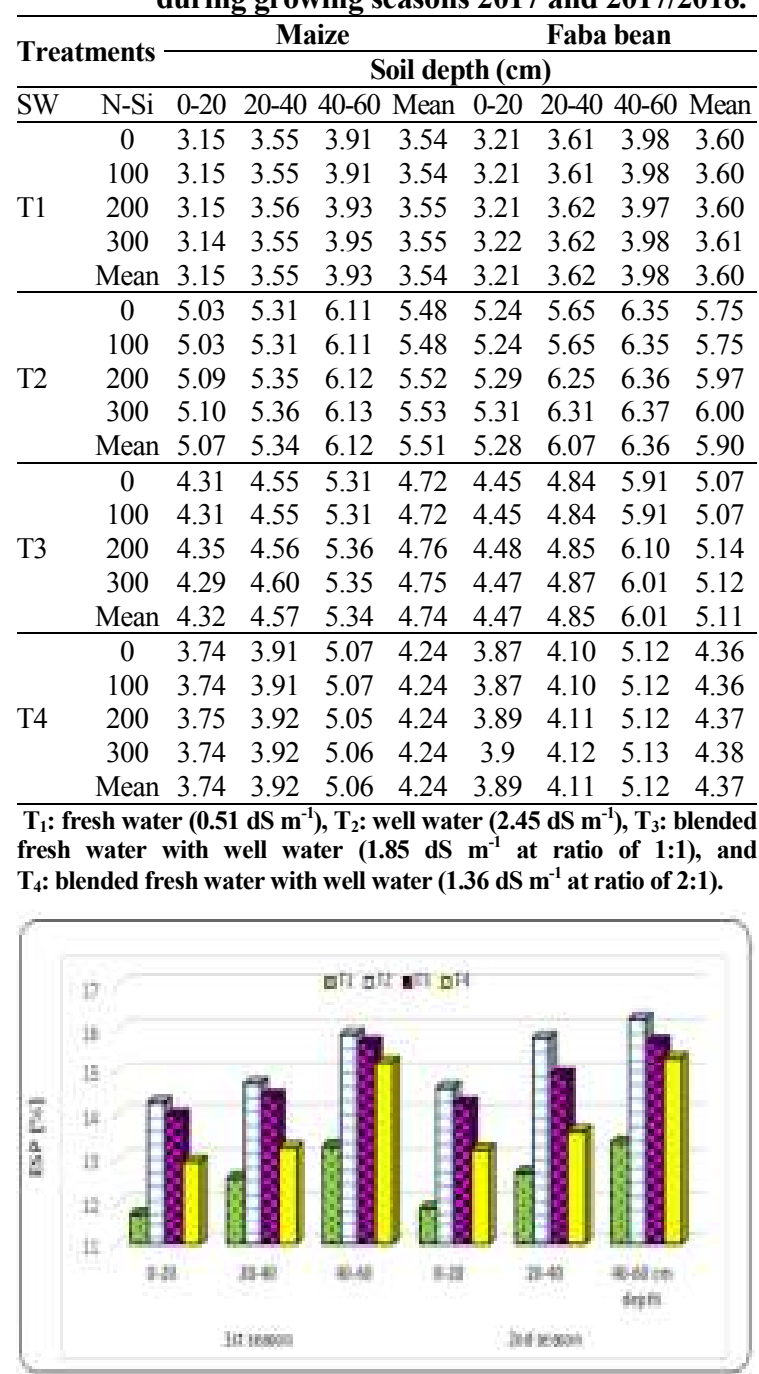

Figure 1. Impact of foliar application with different concentrations nano-silica and different salinity of irrigation water on Exchangeable sodium percentage after harvesting of maize $\left(1^{\text {st }}\right.$ season $)$, and faba bean $\left(2^{\text {nd }}\right.$ season $)$, during growing seasons 2017/2018.

2. Anatomical structure of maize and faba bean roots and leaves

Cross sections of maize and faba bean roots and leaves at 30 and 35 days after sowing of maize and faba bean plants, respectively are illustrated in Table 4, 5 and Figs. 2, 3, 4, 5 and 6. Generally, all anatomical characteristics of roots and leaves were changed by increasing the salinity of irrigation water and reached to lowest value at $\mathrm{T}_{2}\left(2.45 \mathrm{dS} \mathrm{m}^{-1}\right)$ without $\mathrm{N}-\mathrm{Si}$.

\section{Roots anatomical structure}

Data in Table 4 show that, the treatment $\mathrm{T} 1$ and $\left(\mathrm{T}_{4}\right)$ with foliar application nano-silica at $300 \mathrm{mg} \mathrm{L}^{-1}$ increased the root diameter of maize and faba bean up to $(22.75,15.54$ and $3.93,5.97 \%)$, diameter of vascular cylinder $(7.95,6.33$ and $1.84,2.96 \mathrm{~mm})$, and thickness of cortex $(22.77,6.02$ and $2.90,1.69 \mathrm{~mm})$, comparing to the control in maize and faba bean roots, respectively. The highest values of big vessel diameter $\operatorname{arch}^{-1}$ were recorded in faba bean root $(95.14$ and $55.50 \mathrm{~mm})$, for $\mathrm{T}_{1}$ and $\mathrm{T}_{4}$ treatments compared to the control. These results may be attributed to the mechanisms to silicon absorbed into Molina caerulea and Sorghum bicolor plants and interacted with polyphenols in cell walls of xylem and affected lignin deposition and biosynthesis as reported by (Parry and Kelso, 1975).

Also, it could be noticed that increasing of the root diameter was reversed upon different tissues comprising the whole section. The conductive tissue increment (xylem tissue) are great importance because it could be involved in the interpretation about vigorous growth then high yielded especially with $300 \mathrm{mg} \mathrm{L}^{-1} \mathrm{~N}-\mathrm{Si}$ for $\mathrm{T}_{1}$ and $\mathrm{T}_{4}$ treatments compared with the control and other treatments.

Moreover, the positive responses of different anatomical characteristics to treatments especially in case $300 \mathrm{mg} \mathrm{L}^{-1} \mathrm{~N}-\mathrm{Si}$ for $\mathrm{T}_{1}$ and $\mathrm{T}_{4}$ treatments comparing with the control and other treatments will be completely reversed upon enhancing vegetative and reproductive growth of treated plants. So, present study revealed those increases of xylem tissue, i.e., the absorption of mineral nutrients and water translocation from roots to leaves thereby, improvement of translocation events directly could be considered a direct effect for increment the final yield.

Table 4. Roots anatomical characteristics of maize and faba bean plants as affected by foliar application with different concentrations with nano-silica and different salinity combination of irrigation water during growing seasons 2017 and 2017/2018.

\begin{tabular}{|c|c|c|c|c|c|c|}
\hline \multirow[b]{2}{*}{ Characters } & \multicolumn{3}{|c|}{ T1 } & \multicolumn{3}{|c|}{ T4 } \\
\hline & Cont. & $\begin{array}{l}\text { N-Si } \\
300 \\
\end{array}$ & $\begin{array}{c}\text { R.C. } \\
( \pm \%)^{* * * *}\end{array}$ & Cont. & $\begin{array}{l}\mathrm{N}-\mathrm{Si} \\
\mathbf{3 0 0}\end{array}$ & $\begin{array}{c}\text { R.C. } \\
( \pm \%)^{* * * *}\end{array}$ \\
\hline Maize & & & & & & \\
\hline$\varnothing$ of root* & 524.25 & 643.50 & 22.75 & 443.94 & 512.92 & 15.54 \\
\hline$\varnothing$ of V.C** & 374.16 & 403.89 & 7.95 & 300.77 & 319.80 & 6.33 \\
\hline $\begin{array}{l}\text { Thickness of } \\
\text { cortex (mm) }\end{array}$ & 139.24 & 170.95 & 22.77 & 174.39 & 184.89 & 6.02 \\
\hline $\begin{array}{l}\varnothing \text { of big } \\
X . V(\mathrm{~mm})\end{array}$ & 31.90 & 33.29 & 4.36 & 24.96 & 31.89 & 27.76 \\
\hline $\begin{array}{l}\text { Length of V. B } \\
(\mathrm{mm})\end{array}$ & 85.62 & 92.68 & 8.25 & 72.29 & 89.97 & 18.44 \\
\hline No. of V.B V.C- & 70.00 & 76.0 & 8.57 & 33.00 & 44.00 & 33.33 \\
\hline
\end{tabular}

Faba bean

Ø of root $(\mathrm{mm}) * 330.93343 .94 \quad 3.93 \quad 299.25317 .13 \quad 5.97$

\begin{tabular}{llllll}
\hline Thickness of & 157.08161 .64 & 2.90 & 126.41 & 128.55 & 1.69
\end{tabular}

\begin{tabular}{llllll} 
cortex $(\mathrm{mm})$ & & & & & \\
\hline$\emptyset$ of V.C** & 175.91179 .14 & 1.84 & 170.11 & 175.14 & 2.96 \\
\hline
\end{tabular}

\begin{tabular}{llllll}
\hline Length of xylem & 104.31123 .18 & 18.09 & 87.83 & 106.83 & 21.63
\end{tabular}

\begin{tabular}{lcccccc}
$\operatorname{arch} V . B^{-1}(\mathrm{~mm})$ & 104.31123 .18 & 18.09 & 87.83 & 106.83 & 21.63 \\
\hline
\end{tabular}

\begin{tabular}{lcccccc}
\hline No. of V.B V.C ${ }^{-1}$ & 10.00 & 11.00 & 10.00 & 8.00 & 8.33 & 4.13 \\
\hline$\varnothing$ of big vessel $^{7} 7.00$ & 13.66 & 95.14 & 6.00 & 9.33 & 55.50
\end{tabular}

$\operatorname{arch}^{-1}(\mathrm{~mm})$

$\emptyset$ of $\operatorname{root}^{*}=1 / 2$ diameter of root $(\mathrm{mm}) \quad \emptyset$ of $\mathrm{V} . \mathrm{C}^{* * *}=1 / 2$ diameter vascular cylinder in root $(\mathrm{mm}) \quad$ R.C. $( \pm \%)^{* * *}=$ Relative of change $( \pm \%)$

$T_{1}$ : fresh water $\left(0.51 \mathrm{dS} \mathrm{m}^{-1}\right)$, and $T_{4}$ : blended fresh water with well water $\left(1.36 \mathrm{dS} \mathrm{m}^{-1}\right.$ at ratio of $\left.2: 1\right)$. Cont. $=$ Control 
Under adverse climatic conditions, foliar application with nano-silica can be increase stem diameter, number of lateral shoots, root length, and these parameters are reflected to anatomical structure of roots (Sivanesan et al. 2010; Marafon and Endres, 2013). Fardous A. Menesy et al., (2018), showed that a raise in the concentration of silica nanoparticles ( $80 \mathrm{ppm})$ has led to an improvement in root diameter, epidermis thickness and cortex thickness compared with the control. Also, foliar spray with potassium silicate (50 or $100 \mathrm{mg} \mathrm{L}^{-1}$ ) helped the plants to overcome the adverse effect of salt and improvement of vegetative growth (Soundararajan et al. 2013). These observations were noticed by previous studies such as sunflowers (Kamenidou et al. 2008); cucumber (Huang et al. 2009); Maize (Suriyaprabha 2012) and Salvia (Soundararajan et al. 2013).

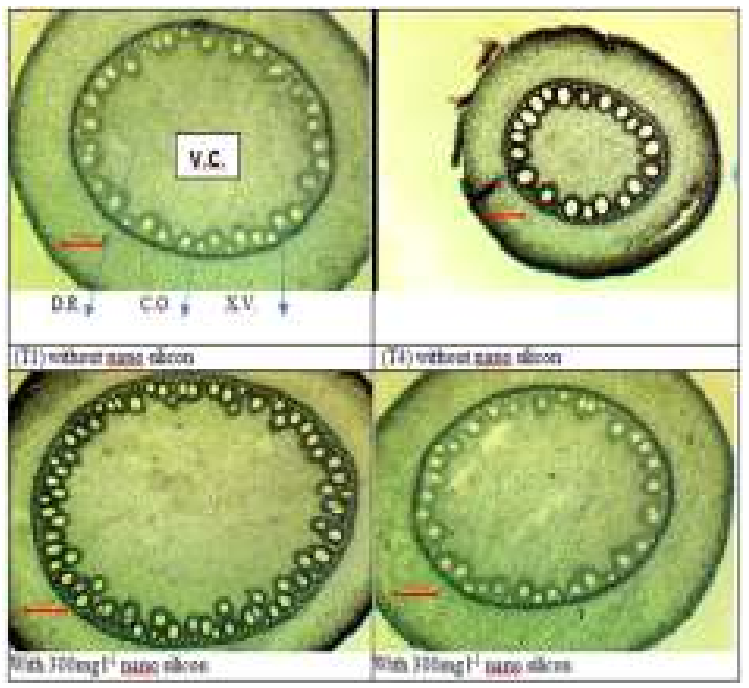

Fig. 2. Transfer section of maize root at $\mathbf{3 0}$ days from sowing as affected by foliar application with different concentrations with nano-silica and different salinity of irrigation water during growing seasons 2017. Where abbreviations: $T_{1}$ : fresh water $\left(0.51 \mathrm{dS} \mathrm{m}^{-1}\right)$ and $\mathrm{T}_{4}$ : blended fresh water with well water $\left(1.36 \mathrm{dS} \mathrm{m} \mathrm{m}^{-1}\right.$ at ratio of 2:1); DR: Diameter of root (mm), VB.: Vascular bundles, Diameter of X. V.; VB: Big xylem vessels per vascular bundle; $\mathrm{CO}=\mathrm{Cortex}$ tissue and VC = Vascular cylinder, (X 32) Bar= $100 \mu \mathrm{m}$.

\section{Leaves anatomical structure}

At 30 DAS, anatomical structure of maize leaves changed from 13.80 and $10.43 \mathrm{~mm}$, for lamina thickness from 16.52 to $4.65 \mathrm{~mm}$, for midrib length and from 7.82 to 31.92 , for number of vesicular bundle/midrib at $300 \mathrm{mg} \mathrm{L}^{-1}$ $\mathrm{N}-\mathrm{Si}$ with $\mathrm{T}_{1}$ and $\mathrm{T}_{4}$ treatments compared to the control. Also, under the same conditions but at 35 DAS , mesophyll thickness and midrib length of faba bean leaves increased from 20.07 to $51.41 \mathrm{~mm}$ and from 35.65 to $103.89 \mathrm{~mm}$, respectively and these results will be positively reflected upon chlorophyll content as shown in Table 5.

Also, the previously mentioned and discussed results of maize and faba bean leaves anatomy of treated plants (at $300 \mathrm{mg} \mathrm{L}^{-1} \mathrm{~N}-\mathrm{Si}$ with $\mathrm{T}_{1}$ and $\mathrm{T}_{4}$ treatments), reveal that increasing of leaf anatomy features compared with control and other treatments, confirmed by vigorous growth of maize and faba bean was positively correlated with photosynthesis pigments content. This confirmed the previously discussed results of anatomy, proved that the best anatomical behavior of maize and faba bean plants under $300 \mathrm{mg} \mathrm{L}^{-1} \mathrm{~N}-\mathrm{Si}$ with $\mathrm{T}_{1}$ and $\mathrm{T}_{4}$ treatments condition which referred mainly due to their induceable best anatomical performance, also due to their ability to develop an internal protective mechanism against such salinity stress adverse effects.

The direct effects of salinity on plants led to increase the storage area of $\mathrm{Na}^{+}$and $\mathrm{Cl}^{-}$and occur by increasing the mesophyll cells, vacuoles and increased leaf succulence (Shabala and makay, 2011). Also, Parida et al., (2004) showed that both of mesophyll and stomatal conductance by $\mathrm{CO}_{2}$ diffusion decreased linearly in leaves with increasing salt concentration.

These results harmony with those Elfeky et al. (2013) who found that the epidermal cells of the NPtreated leaves of anise plants became larger in size and the thickness of mesophyll tissue was greater compared to control.

Rezende et al., (2018) cleared that pigment content, stomatal density and leaf blade thickness in cape gooseberry plant were drastically reduced by increased salt level and when supply with silicon $\left(1.0 \mathrm{~g} \mathrm{~L}^{-1}\right)$ has successfully mitigated the effect of salinity at $0.5 \% \mathrm{NaCl}$.

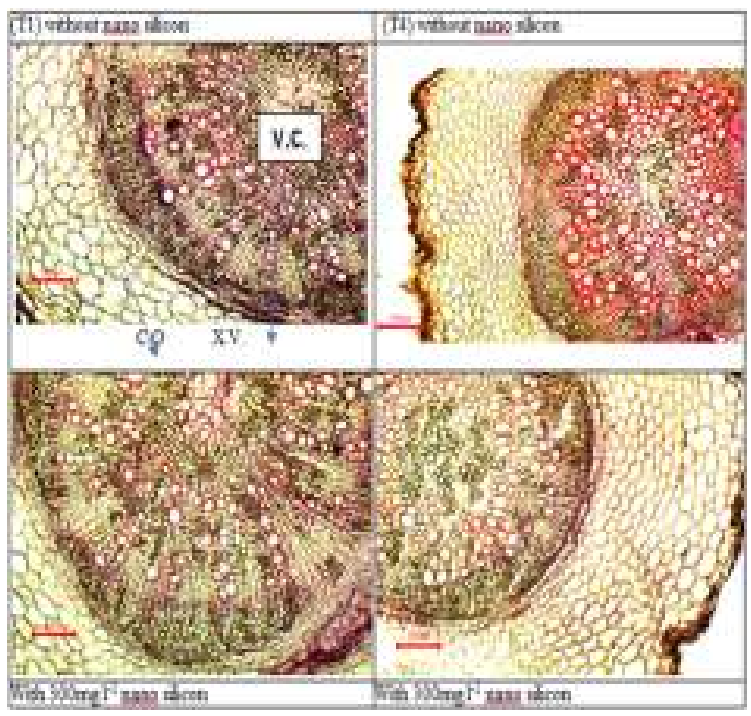

Fig. 3. Transfer section of vicia faba root at 35 days from sowing as affected by foliar application with different concentrations with nano-silica and different salinity of irrigation water during growing seasons 2017. Where abbreviations: $T_{1}$ : fresh water $\left(0.51 \mathrm{dS} \mathrm{m}^{-1}\right)$ and $T_{4}$ : blended fresh water with well water $\left(1.36 \mathrm{dS} \mathrm{m}^{-1}\right.$ at ratio of 2:1); DR: Diameter of root (mm), VB.: Vascular bundles, Diameter of X. V.; VB: Big xylem vessels per vascular bundle; $\mathrm{CO}=\mathrm{Cortex}$ tissue and $\mathrm{VC}=$ Vascular cylinder, (X 32) Bar $=100 \mu \mathrm{m}$ 
Table 5. Leaves anatomical characteristics of Maize and Faba bean as affected by foliar application with different concentrations nano-silica and different salinity of irrigation water during growing seasons 2017 and 2017/2018.

\begin{tabular}{|c|c|c|c|c|c|c|}
\hline & \multicolumn{3}{|c|}{ T1 } & \multicolumn{3}{|c|}{ T4 } \\
\hline Characters & Cont. & N-Si 300 & R.C. $\pm(\%)^{* * *}$ & Cont. & N-Si 300 & R.C. $\pm(\%)^{* * *}$ \\
\hline Maize & & & & & & \\
\hline Thickness of lamina (mm) & 78.63 & 85.84 & 13.8 & 61.15 & 67.53 & 10.43 \\
\hline Thickness of midrib length (mm) & 399.87 & 465.90 & 16.52 & 361.87 & 378.71 & 4.65 \\
\hline Thickness of midrib width (mm) & 918.00 & 1053.93 & 14.7 & 809.17 & 826.50 & 1.54 \\
\hline Thickness of big V.B midrib (mm) & 72.23 & 77.14 & 6.83 & 68.49 & 70.20 & 2.50 \\
\hline Diameter of big X.V V.B ${ }^{-1}(\varnothing \mathrm{mm})$ & 21.14 & 22.15 & 4.77 & 13.47 & 17.20 & 27.69 \\
\hline No. of V.B midrib ${ }^{-1}$ & 21.33 & 23.00 & 7.82 & 15.66 & 20.66 & 31.92 \\
\hline Faba bean & & & & & & \\
\hline Upper epidermis & 17.34 & 18.84 & 8.65 & 4.82 & 7.69 & 59.54 \\
\hline Lower epidermis & 10.08 & 13.76 & 36.50 & 4.17 & 7.57 & 81.53 \\
\hline Palisade & 57.40 & 82.50 & 43.72 & 25.1 & 46.00 & 83.26 \\
\hline Mesophyll & 175.30 & 210.50 & 20.07 & 84.6 & 128.1 & 51.41 \\
\hline Midrib width $(\mu)$ & 302.43 & 349.03 & 15.40 & 148.22 & 286.85 & 93.52 \\
\hline Bundle length $(\mu)$ & 83.30 & 113.00 & 35.65 & 35.4 & 72.8 & 103.89 \\
\hline No. of Arches & 6.00 & 9.00 & 50.00 & 3.00 & 5.00 & 66.66 \\
\hline No. of vessels/Arch & 4.00 & 5.00 & 25.00 & 3.00 & 5.00 & 66.66 \\
\hline Diameter of vessel $\varnothing$ & 7.79 & 7.93 & 1.79 & 3.02 & 4.42 & 46.35 \\
\hline
\end{tabular}

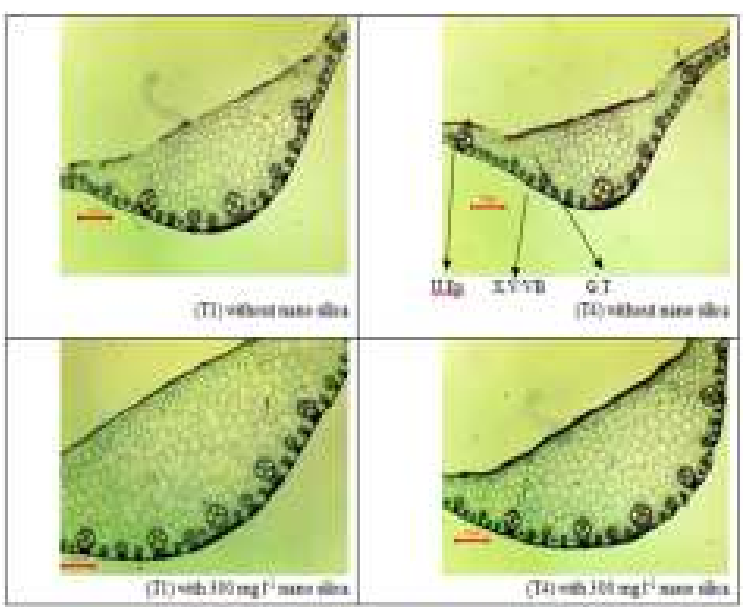

Fig. 4. Transfer section of maize leaves at 30days from sowing as affected by foliar application with different concentrations of nano-silica and different levels of irrigation water salinity during growing seasons 2017. Where abbreviations: T1: fresh water $\left(0.51 \mathrm{dS} \mathrm{m}^{-1}\right)$ and T4: blended fresh water with well water $(1.36 \mathrm{dS}$ $\mathrm{m}^{-1}$ at ratio of 2:1); U.Ep.: Epidermis cells, G.T: Ground tissue cells, VB.: Vascular bundles, $X$. V. / VB: Big xylem vessels per vascular bundl.

\section{Total chlorophyll content}

Table (6) depicted the results of total chlorophyll in leaves of maize and faba bean plants. Highly significant variations in total chlorophyll content were observed under both of foliar application with different concentrations with nano-silica and different salinity of irrigation water treatments. For irrigation water treatments, $\mathrm{T}_{3}$ (Fresh irrigation water), recorded the highest values in total chlorophyll content compared to the other water treatment in both of maize and faba bean plants. The same trend, total chlorophyll content was increased with increasing of foliar application with nano-silica concentration, which the increasing percentage between the lowest concentration (N-Si $100 \mathrm{mg} \mathrm{L}^{-1}$ ) and the highest concentration (N-Si 300 $\mathrm{mg} \mathrm{L} \mathrm{L}^{-1}$ ), increased from to 23.90 and 34.50 , to 46.5 and 38.5 with $\mathrm{T}_{4}$ treatment for maize and faba bean plants, respectively.
These results are great interest, because they are lightly considered direct effect for more dry matter production and distribution in shoots of maize and faba bean plants as affected by different applied treatments. The simulative effect of different applied treatments might be due to their anti-oxidantal scavenging effect to be protected chloroplasts and prevented chlorophyll degradation by the toxic reactive oxygen radicals which internally generated during salinity stress.

These results agreement with Moussa (2006) cleared that $\mathrm{Si}$ may act to alleviate salt stress in maize plants by decreasing the permeability of plasma membranes, maintenance of cell form, structure and enhancement chlorophyll content as well as photosynthetic activity. Also, Ahmad et al. (1992) showed that addition of small amount of soluble silicon enhanced salt tolerance of wheat and enhanced the growth of salt treated barley, by improving the chlorophyll content and photosynthetic activity of leaf cell organelles of barley (Bradbury and Ahmad, 1990).

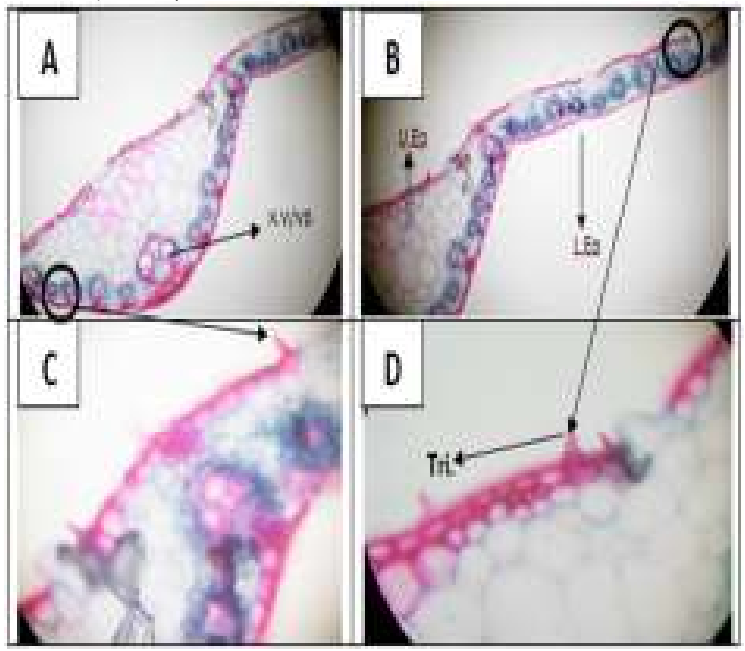

Fig. 5. Transfer section of maize leaves at 30days from sowing as affected by foliar application with $\mathbf{3 0 0}$ $\mathrm{mg} \mathrm{l}^{-1}$ nano silica and blended fresh water with well water (1.36 dS m$~^{-1}$ at ratio of $\left.2: 1\right)$ during growing seasons 2017. Where: $A$ and $B=10 X$,

$\mathrm{C}$ and $\mathrm{D}=40 \mathrm{X}$, U.Ep.: Epidermis cells, VB.: Vascular bundles, X. V/ VB: Big xylem vessels / vascular bundl, Tri.: Trichomes in Upper Epidermis. 


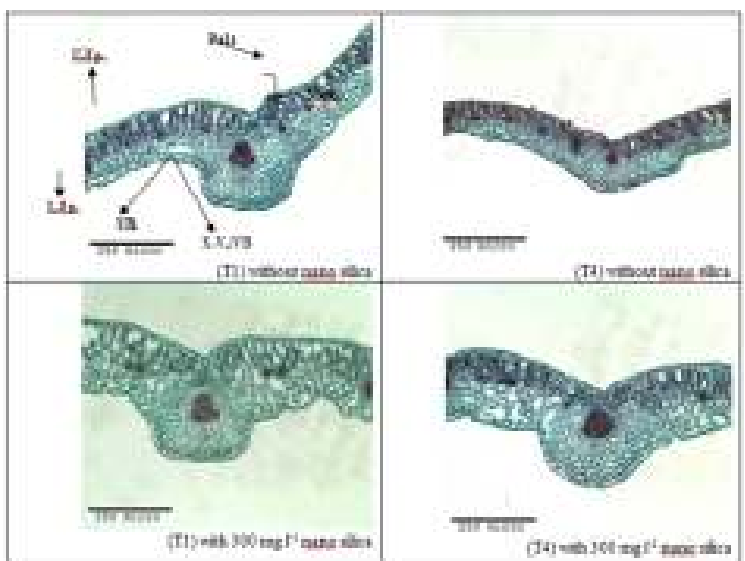

Fig. 6. Transfer section of faba bean leaves at 30days from sowing as affected by foliar application with different concentrations of nano-silica and different levels of irrigation water salinity during growing seasons 2017. Where abbreviations: T1: fresh water (0.51 dS m-1) and T4: blended fresh water with well water $(1.36 \mathrm{dS} \mathrm{m}-1$ at ratio of 2:1); U.Ep.: Upper epidermal cells, L.Ep.: Lower epidermal cells, Meso.: Mesophyll layer, Pal.t: palisade tissue, VB.: Vascular bundles, X. V./VB: Big xylem vessels per vascular bundl.

\section{The productivity of Maize and faba bean}

Grain and straw yield ( $t /$ fed.) of maize and faba bean plants as affected by different combinations of irrigation water $\left(0.51,2.45,1.85\right.$ and $\left.1.36 \mathrm{dS} \mathrm{m} \mathrm{m}^{-1}\right)$, and foliar application with different concentrations of nano-silica $\left(0,100,200\right.$ and $\left.300 \mathrm{mg} \mathrm{L}^{-1}\right)$ are illustrated in Table 7.

Treatment $T_{2}$ showed a significant recorded the lowest values of grain and straw yield of the two plants Maize and Faba bean especially without nano- silica, but, the productivity increased with increase the nano- silica concentration compared to Treatment 1 which recorded the highest productivity values with different silica concentrations, that meaning, the high concentration of nano-silica played important role in the enhancement the soil properties then increase the productivity of the two studied crops. On the other hand, $\mathrm{T}_{4}\left(1.36 \mathrm{dS} \mathrm{m}^{-1}\right)$, recorded the highest values 4.22 and $5.32 \mathrm{Mg} \mathrm{Fed}^{-1}$ in grain and straw yield of maize plants and 1.74 and $1.85 \mathrm{Mg} \mathrm{Fed}^{-1}$ in grain and straw yield of faba bean plants with foliar application with $300 \mathrm{mg} \mathrm{L}^{-1}$ of nano-silica as compared to the other concentrations respectively. These results may be due to silicon reduces the adverse impact of abiotic stresses by the improved photosynthetic activity, enhanced $\mathrm{K} / \mathrm{Na}$ selectivity ratio, increased enzyme activity and increased concentration of soluble substances in xylem, resulting in limited sodium absorption by plants (Chanchal et al, 2016). This also could be due to the pronounced enhanceable effect of the same treatments on growth behavior, metabolie activity (chlorophyll and carbohydrate content), the anti-oxidant bioconstituents, i.e., carotenoids content and the anatomical performance, all of them positively correlated with high yield, especially under salinity stress conditions.

Table 6. Chlorophyll content in the leaves as affected by different nano-silica concentration and water salinity combination of Maize and Faba bean during growing seasons 2017 and 2017/2018.

\begin{tabular}{|c|c|c|c|c|c|c|c|c|c|c|}
\hline \multirow{2}{*}{ Treatments } & \multicolumn{5}{|c|}{ Maize } & \multicolumn{5}{|c|}{ Faba bean } \\
\hline & Cont. & N-Si 100 & N-Si 200 & $\mathrm{~N}-\mathrm{Si} 300$ & F.test & Cont. & N-Si 100 & N-Si 200 & N-Si 300 & F. test \\
\hline $\mathrm{T}_{1}$ & $28.1 \mathrm{i}$ & $33.1 \mathrm{~g}$ & $44.6 \mathrm{~d}$ & $52.4 \mathrm{a}$ & $* *$ & $36.1 \mathrm{e}$ & $40.5 \mathrm{c}$ & $41.8 \mathrm{~b}$ & $51.1 \mathrm{a}$ & $* *$ \\
\hline $\mathrm{T}_{2}$ & $19.7 \mathrm{~m}$ & $21.1 \mathrm{k}$ & $33.4 \mathrm{~g}$ & $42.2 \mathrm{e}$ & ** & $18.5 \mathrm{p}$ & $21.4 \mathrm{o}$ & $22.6 n$ & 28.71 & ** \\
\hline $\mathrm{T}_{3}$ & 20.21 & $22.8 \mathrm{j}$ & $40.5 \mathrm{f}$ & $45.4 \mathrm{c}$ & $* *$ & $27.8 \mathrm{~m}$ & $30.2 \mathrm{k}$ & $31.5 \mathrm{j}$ & $32.6 \mathrm{i}$ & $* *$ \\
\hline $\mathrm{T}_{4}$ & $21.2 \mathrm{k}$ & $23.9 \mathrm{~h}$ & $44.5 \mathrm{~d}$ & $46.5 \mathrm{~b}$ & $* *$ & $31.2 \mathrm{j}$ & $34.5 \mathrm{f}$ & $36.4 \mathrm{e}$ & $38.0 \mathrm{~d}$ & $* *$ \\
\hline$\overline{\text { F. tes }}$ & ** & ** & ** & ** & & ** & ** & $* *$ & ** & \\
\hline
\end{tabular}

$T_{1}$ : fresh water $\left(0.51 \mathrm{dS} \mathrm{m}^{-1}\right), T_{2}$ : well water $\left(2.45 \mathrm{dS} \mathrm{m}^{-1}\right), T_{3}$ : blended fresh water with well water $\left(1.85 \mathrm{dS} \mathrm{m}^{-1}\right.$ at ratio of 1:1), and $\mathrm{T}_{4}$ : blended fresh water with well water $\left(1.36 \mathrm{dS} \mathrm{m}^{-1}\right.$ at ratio of $\left.2: 1\right)$.

Table 7. The productivity (t/fed.) as affected by different nano-silica concentration and water salinity combination of Maize and Faba bean during growing seasons 2017 and 2017/2018.

\begin{tabular}{|c|c|c|c|c|c|c|c|c|c|c|}
\hline \multirow{3}{*}{ Treatment } & \multicolumn{5}{|c|}{ Grain (Mg Fed. $^{-1}$ ) } & \multicolumn{5}{|c|}{ Straw (Mg Fed. $\left.{ }^{-1}\right)$} \\
\hline & \multicolumn{10}{|c|}{ Maize } \\
\hline & Cont. & N-Si 100 & N-Si 200 & N-Si 300 & F. test & Cont. & N-Si 100 & N-Si 200 & N-Si 300 & F. test \\
\hline$\overline{\mathrm{T}_{1}}$ & $2.75 \mathrm{j}$ & $3.12 \mathrm{~g}$ & $3.86 \mathrm{~d}$ & $4.29 \mathrm{a}$ & $* *$ & $2.91 \mathrm{k}$ & $4.15 \mathrm{~g}$ & $4.65 \mathrm{~d}$ & $5.36 \mathrm{a}$ & $* *$ \\
\hline $\mathrm{T}_{2}$ & $1.67 \mathrm{n}$ & $2.61 \mathrm{k}$ & $3.14 \mathrm{~g}$ & $3.70 \mathrm{e}$ & $* *$ & $1.78 \mathrm{n}$ & $3.45 \mathrm{j}$ & $4.16 \mathrm{~g}$ & $4.37 \mathrm{f}$ & $* *$ \\
\hline $\mathrm{T}_{3}$ & $2.42 \mathrm{~m}$ & $2.84 \mathrm{i}$ & $3.68 \mathrm{f}$ & $3.95 \mathrm{c}$ & $* *$ & $2.58 \mathrm{~m}$ & $3.87 \mathrm{i}$ & $4.56 \mathrm{e}$ & $4.98 \mathrm{c}$ & $* *$ \\
\hline $\mathrm{T}_{4}$ & 2.561 & $3.00 \mathrm{~h}$ & $3.86 \mathrm{~d}$ & $4.22 \mathrm{~b}$ & $* *$ & 2.651 & $4.01 \mathrm{~h}$ & $4.64 \mathrm{~d}$ & $5.32 \mathrm{~b}$ & $* *$ \\
\hline F. test & $* *$ & $* *$ & $* *$ & $* *$ & & $* *$ & $* *$ & $* *$ & $* *$ & \\
\hline \multicolumn{11}{|l|}{ Faba bean } \\
\hline $\mathrm{T}_{1}$ & $1.51 \mathrm{i}$ & $1.84 \mathrm{c}$ & $1.98 \mathrm{~b}$ & $2.15 \mathrm{a}$ & $* *$ & $1.55 \mathrm{f}$ & $1.98 \mathrm{c}$ & $2.05 \mathrm{~b}$ & $2.10 \mathrm{a}$ & $* *$ \\
\hline $\mathrm{T}_{2}$ & $0.30 \mathrm{~s}$ & $0.41 \mathrm{r}$ & $0.59 \mathrm{q}$ & $0.71 \mathrm{p}$ & $* *$ & $0.34 \mathrm{q}$ & $0.52 \mathrm{p}$ & $0.61 \mathrm{o}$ & $0.78 \mathrm{n}$ & $* *$ \\
\hline $\mathrm{T}_{3}$ & $0.84 \mathrm{o}$ & $1.15 \mathrm{n}$ & $1.29 \mathrm{~m}$ & $1.44 \mathrm{k}$ & $* *$ & $0.85 \mathrm{~m}$ & 1.191 & $1.34 \mathrm{k}$ & $1.54 \mathrm{i}$ & $* *$ \\
\hline $\mathrm{T}_{4}$ & 1.321 & $1.55 \mathrm{j}$ & $1.61 \mathrm{e}$ & $1.74 \mathrm{~d}$ & $* *$ & $1.41 \mathrm{j}$ & $1.58 \mathrm{f}$ & $1.71 \mathrm{e}$ & $1.84 \mathrm{~d}$ & $* *$ \\
\hline F test & $* *$ & $* *$ & $* *$ & $* *$ & & $* *$ & $* *$ & $* *$ & $* *$ & \\
\hline
\end{tabular}

$T_{1}$ : fresh water $\left(0.51 \mathrm{dS} \mathrm{m}^{-1}\right), T_{2}$ : well water $\left(2.45 \mathrm{dS} \mathrm{m}^{-1}\right), \mathrm{T}_{3}$ : blended fresh water with well water $\left(1.85 \mathrm{dS} \mathrm{m}^{-1}\right.$ at ratio of 1:1), and $\mathrm{T}_{4}$ : blended fresh water with well water $\left(1.36 \mathrm{dS} \mathrm{m}^{-1}\right.$ at ratio of $\left.2: 1\right)$.

\section{CONCLUSION}

In the present work, nano-silica proved its significant importance role for enhancement soil properties, anatomical characteristics, grain and straw yields of maize and faba bean. Yields of grain and straw were positively affected by nano-silica having higher values compared to without application of nano-silica 
under irrigation by different level of salinity in irrigation water. Among four different nano-silica concentrations i.e., $0,100,200$, and $300 \mathrm{mg} \mathrm{L}^{-1}$, the treatment of $300 \mathrm{mg} \mathrm{L}^{-1}$ nano-silica had to mitigation of salt stress effect as well as improvement soil properties, anatomical structure and productivity of maize and faba bean plants. Based on these results, it could be concluded that $300 \mathrm{mg} \mathrm{L}^{-1}$ of nano-silica suspension is the best concentration for maize and faba bean crops when irrigation by saline water.

\section{REFERENCES}

Abdul Qados A. M. (2015). mechanism of nano siliconmediated alleviation of salinity stress in Faba bean (Vicia faba L.) plants. American Journal of Experimental Agric., 7(2), 78-95.

Ahmad, R. ; S. Zaheer and S. Ismail (1992). Role of silicon in salt stress tolerance of wheat (Triticum aestivum L.). Plant Sci., 85: 43-50

Amer, M. M.; M. A. Aiad and S.H. Rashed. (2015) Effect of Algae and Compost Extracts on Some Soil Proprieties and Its Productivity Under Low Quality Irrigation Water in North Nile Delta Region, J. Soil Sci. and Agric. Eng., Mansoura Univ., Vol. 6 (11): $1365-1380$

An P, Inanaga S. ; Li X, Schimizu and H. E. Tanimoto (2003). Root characteristics in salt tolerance. Root Res 12:125-132.

Awang YB; J.G. Atherton and AJ. Taylor (1993). Salinity effects on strawberry plants in rockwool. 1. Growth and leaf water relations. J Hortic Sci 68:783-790.

Ayres, R.S. and D.W. Westcot. (1977). Water Quality for Agriculture. Irrigation and Drainage Paper No. 29. Food and Agriculture Organization of the United Nations. Rome.

Bao-Shan L. ; D. Shao-qi ; L. Chun-hui ; F. Li-jun ; Q. Shu-chun and Y. Min (2004). Effect of TMS (nanostructured silicon dioxide) on growth of Changbai larch seedlings. J Forest Res15:138-140

Belda R.M. and L.C. Ho (1993). Salinity effects on the network of vascular bundles during tomato fruit development. J Hortic Sci 68:557-564.

Bradbury M. and R. Ahmad (1990). The effect of silicon on the growth of Prosopis juliflora growing in saline soil. Plant Soil, 125: 71-4

Campbell, D.J. (1994) Determination and use of bulk density in relation to soil compaction. In Soane and Ouwerk (Eds). Soil Compaction in Crop Production. Elsevier, London, Amsterdam.

Chanchal M. C.H. ; RitiThapar Kapoor and G. Deepak (2016). Alleviation of abiotic and biotic stresses in plants by silicon supplementation. Sci. Agri.13 (2): $59-73$

Cram J.W.; P.G. Torr and D.A. Ross (2002). Salt allocation during leaf development and leaf fail in mangroves. Trees 16:112-19

Dajic, Z. (2006). Salt stress, in Physiology and Molecular Biology of Salt Tolerance in Plant, Madhava, Rao, K.V., Raghavendra, A.S., and Janardhan, Reddy, K., Eds., Dordrecht: Springer-Verlag, pp. 41-99.
Delphine S. ; A. Alvino; M. Zacchini and F. Loreto (1998). Consequence of salt stress on conductance to $\mathrm{CO} 2$ diffusion, Rubisco characteristics of spinach leaves. Aust Journal Plant Physiol 25:395-402

Elfeky S.A. ; M.A. Mohammed; M.S. Khater ; Y.A.H. Osman and E. Elsherbini (2013). Effect of magnetite Nano-Fertilizer on Growth and yield of Ocimum basilicum L. Int. J. of Ind. Med., 46 (3): 1286-1293.

El-Shahawy, M. I. and Ragab, M.M (2005). Demonstration of Sustainable Safe Reuse of Drainage Water in Agriculture at North Delta, Agricultural Research Center, Regional Council for Agricultural Research and Extension, Annual Report

Epstein E. (2009). Silicon Its manifold roles in plants. Ann. Appl. Biol 155:155-160.

FAO. (1992). The use of saline waters for crop production Irrigation and Drainage Paper 48 Chapter 3 Examples of use of saline waters for irrigation

Fardous A. Menesy; M. M. Khalfallah, M. Nahed Rashed and A. K. Maaty (2018). Response of Pimpinella anisum L. Plant For Graphite and Silica Nanoparticles. J. Sus. Agric .Sci. 44, No.1, pp.1 12.

Flávio F. B.; V. F. Marcos; R. G. Hans and D. F. Pedro (2008). Growth and yield of corn irrigated with saline water. Sci. Agric. (Piracicaba, Braz.), 65(6) 574-580.

Garcia, I. (1978). Soil water engineering laboratory manual. Department of agric. and chemical engineering. Colorado State univ., Fortacollin Colorado, USA.

Geriach, D. (1977). Botanshe micotechnik. Eine einfuhrung theime veriag, Stuttgart. BRO

Glick B. R . (2012) . Plant growth - promoting bacteria: mechanisms and applications. Scientifica :1-15

Gomez, K.A. and A.A, Gomez (1984). Statistical procedures for Agric. Res., $2^{\text {nd }}$ edition. John Wiley and Sons, New York, 680.

Greenway H. and Munns R. (1980). Mechanisms of salt tolerance in nonhalophytes. Annu Rev Plant Physiol 31:149-190

Haghighi M. ; Z. Afifipour; M., Mozafarian (2012). The effect of N-Si on tomato seed germination under salinity levels. J Biol Environ Sci. 6(16),87-90

Hashemi A. ; A. Abdolzadeh and H.R. Sadeghipour (2010). Beneficial effects of silicon nutrition in alleviating salinity stress in hydroponically grown canola, Brassica napus L., plants. Soil Sci. Plant Nutr.; 56:244-253.

$\mathrm{Hu}$ Y. and U. Schmidhalter (2001). Reduced cellular crosssectional area in the leaf elongation zone of wheat causes a decrease in dry weight deposition under saline conditions. Aust J Plant Physiol 28:165-170.

Huang S. ; R. Li; Z. Zhang; L. Li and X. Gu (2009). The genome of the cucumber, Cucumissativus L. Nature Genet. 41, 1275-1281

Jackson, M.L. (1958). Soil Chemical Analysis. Constable. Co. Ltd.London 
Junghans U. ; A. Polle; P. Duchting; E.Weiller; B. Kuhlman; F. Gruber and T. Teichmann (2006). Adaptation to high salinity in poplar involves changes in xylem anatomy and auxin physiology. Plant Cell Environ 29:1519-1531.

Kalteh M., Z.T.Alipour, S.Ashraf, M.M. Aliabadi and A.F. Nosratabadi (2014). Effect of silica nanoparticles on basil (Ocimum basilicum) under salinity stress. J. Chem. Health Risks, 4:49-55

Kamenidou S., T.J. Cavins and S.M. Marek (2008). Silicon supplements affect horticultural traits of greenhouse-produced ornamental sunflowers. Hort. Science. 43, 236-239.

Kılıç S., K. Çavuşoğlu and K. Kabar (2007). Effects of 24epibrassinolide on salinity stress induced inhibition of seed germination, seedling growth and leaf anatomy of barley. SDU Fac Arts Sci J Sci. 2:4152.

Liang Y., W. Sun, Y.G. Zhu and P. Christie (2007). Mechanisms of silicon mediated alleviation of abiotic stresses in higher plants: a review. Environ Poll.147,422-428.

Liang Y.C., Q.I.N. Chen, Q. Liu, W. Zhang and R. Ding (2003). Exogenous silicon (Si) increases antioxidant enzyme activity and reduces lipid peroxidation in roots of salt-stressed barley (Hordeum vulgare L.). J. Plant Physiol 160,11571164

Ludders P.C. and V. Kaminski (1991). Einflub von $\mathrm{NaCl}$ auf die stomata- und blatthaardichte bei feigen in unterschiedlicher luftfeuchte. Mitteilungen Klosterneuburg 41:76-78.

Ma, J.F. and N. Yamaji (2008). Functions and transport of silicon in plants. Cell Mol. Life Sci. 65,3049- 3057.

Marafon A.C. and L. Endres (2013). Silicon: fertilization and nutrition in higher plants. Amaz.J. Agric. Environ. Sci. 56, 380-388

Meyer, J.H. and M.G. Keeping (2000). Review of Research Into the Role Of Silicon For Sugarcane Production, Proc. S. Afr. Sug. Technol. Ass., 74

Moussa H.R. (2006). Influence of Exogenous Application of Silicon on Physiological Response of Saltstressed Maize (Zea mays L.). Inter. J. Agric. \& Bio., 1560-8530/2006/08-2-293-297

Page A.L.R., H. Miller and D.R. Keeney, (1982). Methods of soil analysis. Part 2: Chemical and Microbiological Properties. 2nd Edition. Agronomy Monograph, No. 9, ASA, CSSA, CSSA and SSSA, Madiso.

Parida A.K.; A. B. Das and B. Mittra (2004). Effects of salt on growth, ion accumulation, photosynthesis and leaf anatomy of the mangrove, Bruguiera parviflora. Trees, 18:167-174 DOI 10. 1007 / s00468-003- 0293-8

Parry, D.W. and M. Kelso, (1975). The distribution of silicon deposits in the root, Molina caerulea L. Moench and Sorghum bicolor L. Moench. Ann. Bot., 39, 995- 1001.
Parveen N. and M.Ashraf (2010). Role of silicon in mitigating the adverse effects of salt stress on growth and photosynthetic attributes of two maize (Zea Mays L.) cultivars grown hydroponically. Pak J Bot. 42(3):1675-1684.

Pimmongkol A. S., Terapongtanakhon and K. Udonsirichakhon (2002). Anatomy of salt-and nonsalt-tolerant rice treated with $\mathrm{NaCl}$. In: 28th Congr. Science and Technology of Thailand, Bangkok, Thailand.

Raafat A., S.A. Habib, I.Z. El-Shami and H.M. El-Antably (1991). The effect of salinity on the anatomical features of tomato plants. Ann Agric Sci 36:307321.

Rezende R., F.A. Rodrigues, J.D. Soares, H.R. Silveira, M. Pasqual and G. G. Dias (2018). Salt stress and exogenous silicon influence physiological and anatomical features of in vitro-grown cape gooseberry. Ciência Rural, sanata maria, v.48: 01,e20170176.

Roohizadeh G., A.Majd and S. Arbabian (2015). The effect of sodium silicate and silica nanoparticles on seed germination and some of growth indices in the Vicia faba L. Trop Plant Res 2(2):85-89

Sabaghnia N. and M. Janmohammadi (2014). Graphic analysis of nano-silicon by salinity stress interaction on germination properties of lentil using the biplot method. Agr Forest29-40:)3(60 .

Shabala, S. and A. mackay (2011). Ion transport in halophytes, Advances in Botanical Research, v.57, n.1,p.151-187. doi: 10.1016/B978-0-12-3876928.00005-9.

Siddiqui M.H., M.H. Al-Whaibi, M. Faisal and A.A. Al Sahli (2014). Nano-silicon dioxide mitigates the adverse effects of salt stress on Cucurbita pepo L. Environ Toxicol Chem 33(11):2429_ 2437. doi:10.1002/etc. 2697

Sivanesan I, M.S. Son, J.P. Lee and B.R. Jeong (2010). Effects of silicon on growth of Tagetespatula L. Boy orange and Yellow boy seedlings cultured in an environment-controlled chamber. Propag.Ornam. Plants. 10, 136-140.

Soundararajan P., I. Sivanesan, E.H. Jo and B.R. Jeong (2013). Silicon promotes shoot proliferation and shoot growth of Salvia splendens under salt stress in vitro. Hort. Environ. Biotechnology. 54, 311-318

Suriyaprabha R, G. Karunakaran, R. Yuvakkumar, V. Rajendran and N. Kannan (2012). Silica nanoparticles for increased silica availability in maize (Zea mays L.) seeds under hydroponic conditions. Curr Nano Sci.8,1-7

Yuvakkumar R., V. Elango, V. Rajendran, N. S Kannan and P. Prabu (2011). Influence of Nanosilica Powder on the Growth of Maize Crop (Zea mays L.). Inter. J. Green Nanotechn.;3,180-190. 
دور النانو سيليكا في تخفيف تأثير الإجهاد الملحي علي بعض خصائص التربة والتركيب التشريحي والاتتاجية لنباتات الفول البلدي والذرة

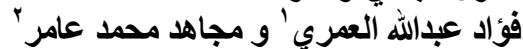

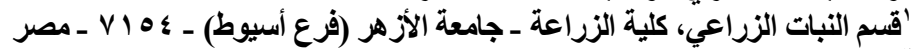

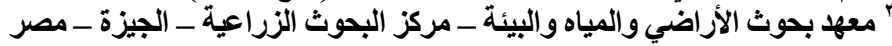

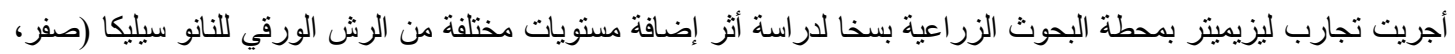

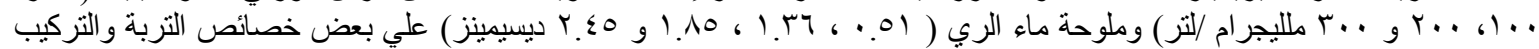

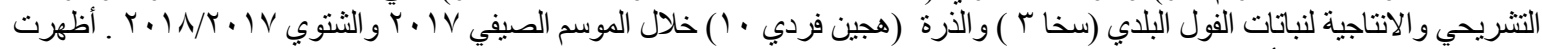

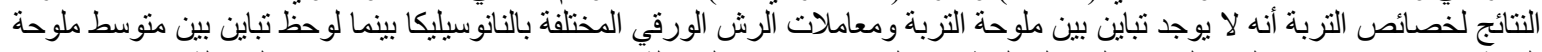

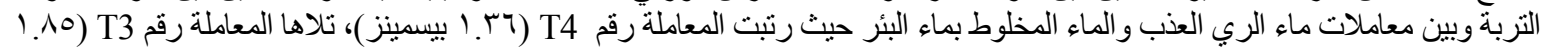

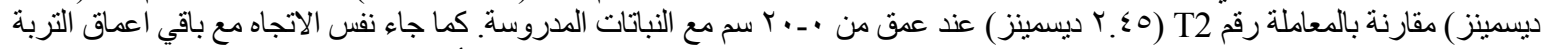

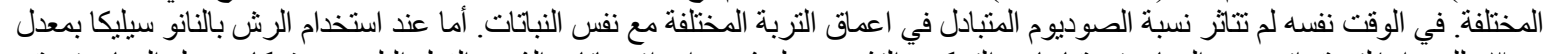

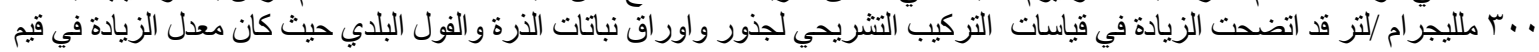

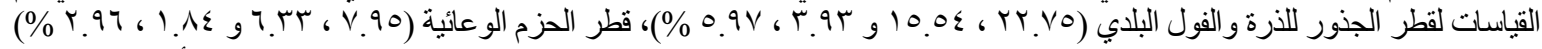

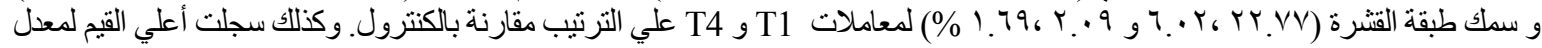

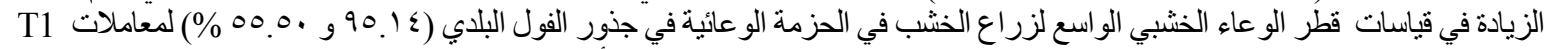

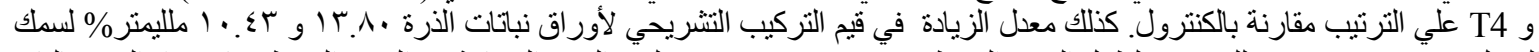

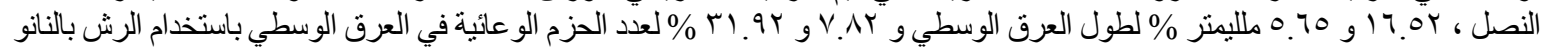

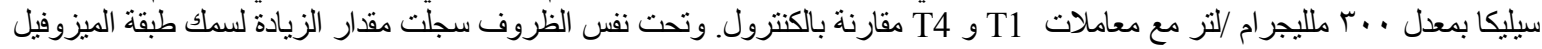

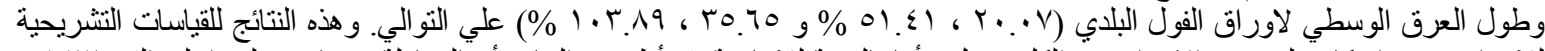

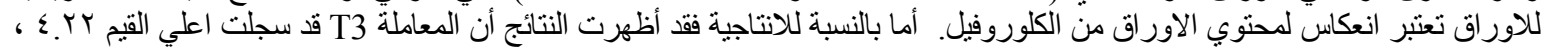

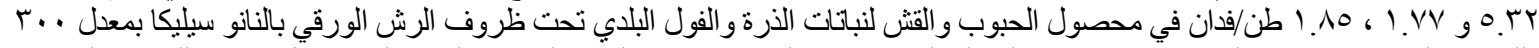

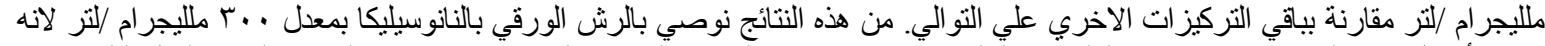

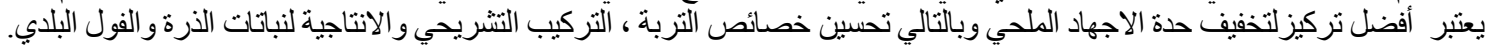

